\title{
Study on Stable Lactation of Jersey Cross Breed
}

\author{
Radhika Thakur*, R.K. Gupta and P.K. Mahajan \\ Department of Basic Sciences, College of Forestry, Dr. Y. S. Parmar University of \\ Horticulture and Forestry Nauni- Solan, Himachal Pradesh-173230, India
}

*Corresponding author

\section{A B S T R A C T}

Keywords

Stability analysis,

Wricke Ecovalence

Model, Lactations,

Milk yield, Jersey

cross breed

Article Info

Accepted:

15 February 2019

Available Online:

10 March 2019
Milk yield data of 4 Jersey cross cows were taken from Dairy Farm of Department of Silviculture and Agroforestry, Dr. Y S Parmar University of Horticulture and Forestry Nauni- Solan, Himachal Pradesh from 19782014. Data were used on stability analysis of milk yield of Jersey cross cows to find out stable lactation. Wricke proposed 'Ecovalence' based on means. Study on Wricke ecovalence indicates a generalized estimate of study of performance based on means under more than two months. Ecovalence is generally expressed in percentage. As percentage of ecovalence $\left(\mathrm{W}_{\mathrm{i}}\right)$ is inversely associated with lactation stability, a low percentage of $\mathrm{W}_{\mathrm{i}}$ indicates high stability of performance. Therefore, lactation 5 was found to be high stable lactation.

\section{Introduction}

The Jersey breed originated on the Island of Jersey, a small British island in the English Channel off the coast of France and the Jersey is one of the oldest dairy breed. Of all major dairy breeds, the Jersey's milk boasts the richest content. The milk is very high in butterfat, which provides a better- tasting product. It is also used for making cheese and butter. Jersey cows are outstanding milk producers, producing more milk per each pound of body weight than other types of bovines. The record for milk production by one cow is held by a Jersey. The Jersey produces more milk on less feed than other dairy breeds. Cross bred Jersey, cow gives 810 litres per day. Jersey cows are characterized by small body size, hardy and adaptable, low maintenance requirement, high feed conversion efficiency, high milk fat content, and good reproductive performance and have been selected for tropical research and development programs (Cunningham and Syrstad 1987; and Nijubi et al., 1992).

\section{Materials and Methods}

In the present study, secondary data on milk yield for thirty seven years from 1978-2014 
month wise, lactation wise for the Jersey and Holstein Friesian crossbred cows were taken from dairy farm of Department of Silviculture and Agroforestry, Dr. Y. S. Parmar University of Horticulture and Forestry, Nauni, Solan, Himachal Pradesh. Lactation $\times$ month interaction was used to find out the stable lactation. Lactation method was considered as lactations up to seven lactations, hence data on milk yield up to seven lactations were subjected to test the effect of different lactations. Four cows each of Jersey crossbred cows were considered up to seven lactations i.e. Lactation 1, Lactation 2, Lactation 3, Lactation 4, Lactation 5, Lactation 6 and Lactation 7. Analysis of variance was performed to test the significance of different lactations for each month separately and pooled analysis of variances was performed. Stability models viz. Wricke's Ecovalence model (1962) was used to identify the stable lactation for the production of milk yield.

\section{Wricke's Ecovalence Model}

Wricke's ecovalence model (1962) was used to estimate the stability of performance based on means over whole lactations in terms of 'ecovalence' $\left(\mathrm{W}_{\mathrm{i}}\right)$ of each lactation as,

$\mathrm{W}_{\mathrm{i}}=\mathrm{X}_{\mathrm{ij}}-\frac{\mathrm{xi}_{\mathrm{i}}}{\mathrm{m}}-\frac{\mathrm{x}_{\mathrm{j}} \mathrm{j}}{\mathrm{l}}+\frac{\mathrm{x}_{\mathrm{n}}}{\mathrm{lm}}$

where, $X_{i j}=$ Mean performance of $i^{\text {th }}$ lactation in $\mathrm{j}^{\text {th }}$ month,

$X_{i}=$ Total of $i^{\text {th }}$ lactation over all months (m), $\mathrm{X}_{\mathrm{j}}=$ Total of $\mathrm{j}^{\text {th }}$ month over all lactation (1),

X...= Total of all lactation (l) over all months (m)

$\mathrm{W}_{\mathrm{i}}$ is expressed in percentage

$\mathrm{W}_{\mathrm{i}}(\%)=\frac{\mathrm{Wi}}{\sum_{\mathrm{i}=1}^{1} \mathrm{WWi}_{1}} \times 100$

Ecovalence is the contribution of each lactation period to the $1 \times \mathrm{m}$ interaction sum of squares. It is generally expressed in percentage. Low percentage of $\mathrm{W}_{\mathrm{i}}$ indicate more stability of lactation period performance and vice-versa.

\section{Results and Discussion}

The study on "Stability analysis of milk yield of Jersey crossbred cows" was carried out to study the performance of different lactations and months with respect to milk yield. Lactation $\times$ month interaction was found to stable lactation. Fadlelmoula et al., (2007) revealed that lactation length was influenced by season $\times$ period of calving interaction. These results were nearly closed by (Das et al., 2003 and Bose et al., 2012). The graphical representation of milk yield and quality against time was a lactation curve whose assessment followed the evaluation of genetic and environmental factors in milk production (Kamidi, 2005).

Data on milk yield for different months from January to December were analyzed separately and pooled analysis of variance was performed. The result obtained from the pooled analysis of variance was used to obtain stable lactation by using stability models i.e.., Wricke's Ecovalence model. Wricke proposed 'Ecovalence' based on means. Study on Wricke ecovalence indicates a generalized estimate of study of performance based on means under more than two months. Ecovalence is generally expressed in percentage. As percentage of ecovalence $\left(\mathrm{W}_{\mathrm{i}}\right)$ is inversely associated with lactation stability, a low percentage of $\mathrm{W}_{\mathrm{i}}$ indicated high stability of performance. Table 1 presents the parameters of Wricke ecovalence model for milk yield of Jersey and Holstein Friesian crossbred cows, respectively.

In Jersey crossbred cows, lactation 5 was having the lowest $\mathrm{W}_{\mathrm{i}}$ value $(8.94 \%)$ of ecovalence. Low percentage of ecovalence 
indicated more stability of performance of lactation 5. Therefore, the lactation 5 was found to be most stable lactation. In lactation 6 , ecovalence value was $11.65 \%$ which also indicated the stability with reference to milk yield. The lactation 1 had the highest value of ecovalence i.e., $19.47 \%$ indicated that lactation 1 was least stable with respect to milk yield.

Table.1 Parameters of Wricke's Ecovalence Model (1962) for stability of milk yield (litres) of Jersey Crossbred cows for different lactations

\begin{tabular}{|c|c|c|c|}
\hline Lactation(s) & Ecovalence $\left.\mathbf{( W}_{\mathbf{i}}\right)$ & $\mathbf{\%}_{\mathbf{i}}$ & Stability Performance \\
\hline Lactation 1 & 38783.13 & 19.47 & 7 \\
\hline Lactation 2 & 30285.03 & 15.20 & 5 \\
\hline Lactation 3 & 26044.93 & 13.07 & 3 \\
\hline Lactation 4 & 27680.39 & 13.89 & 4 \\
\hline Lactation 5 & 17802.17 & 8.94 & 1 \\
\hline Lactation 6 & 23214.17 & 11.65 & 2 \\
\hline Lactation 7 & 35410.87 & 17.77 & 6 \\
\hline
\end{tabular}

The lactations in descending order of their stability with reference to milk yield was as lactation $5(8.94 \%)$, lactation $6(11.65 \%)$, lactation 3 (13.07\%), lactation 4 (13.89\%), lactation 2 (15.20\%), lactation 7 (17.77\%) and lactation $1(19.47 \%)$. Hence parameters of Wricke's ecovalence model, indicated that the lactation 5 was most stable lactation and lactation 1 was found to be most unstable lactation for Jersey crossbred cows.

Summary and conclusion of the study are as follows: 37 years secondary data on milk yield of Jersey crossbred cows were collected for seven lactations/months i.e. lactation 1 to lactation 7/ January to December. In Jersey crossbred cows, the performance with respect to milk yield of lactation 4 was found to be best with mean 227.49 litres and significantly different with the remaining lactations. The lactation 1 had minimum value of milk yield with mean 167.53 litres and significantly different with the remaining lactations. It was also observed that there was an increasing trend in milk yield with increasing in lactation up to lactation 4 and milk yield declined after lactation 4. In case of months, maximum milk yield was found in July month with mean 247.66 litres and significantly different with the remaining months. Minimum value of milk yield was found in the month November with mean 159.27 litres and was statistically at par with month February with mean 160.84 litres and significantly different with the remaining months.

Best performance with respect to milk yield was found in the lactation 5 in month July with value 305.50 litres and significantly different with the remaining lactations in same lactation (i.e. lactation 6). Minimum milk yield (38.88 litres) was extracted from lactation 1 in month December and significantly different with the remaining lactations in same lactation (i.e. lactation1).

According Wricke's Ecovalence model, low percentage of ecovalence indicate the high stability. According to Wricke's Ecovalence model, lactation 5 of Jersey crossbred cows had ecovalence value $8.94 \%$. It indicated that the lactation 5 was most stable lactation. Therefore, the lactation 5 was most stable lactation for Jersey crossbred cows respectively. 


\section{References}

Bose L K, Nagaraju M and Singh O N. 2012. Genotype $\times$ Environment interaction and stability analysis of lowland rice genotypes. Journal of Agricultural Sciences, 57(1): 1-8.

Cunningham E P and Syrstad O. 1987.Types and breeds of tropical and temperate cattle. In: crossbreeding Bosindicus and Bos Taurus for milk production in the Tropics. FOA, Rome. Paper 68.

Das S, Choudhary D N and Maurya K R. 2003. Stability analysis in cucumber. Journal of Applied Biology., 13(1/2): 58-61.

Fadlelmoula A A, Abu Nekheila A M and Yousif I A. 2007.Lactation performance of Crossbred dairy cows in the Sudan.
Research Journal of Agriculture and Biological Science, 3(5): 389-393.

Ferreira D F, Demetrio C G, Frederick B, Machado A and Vencovsky R. 2006. Statistical models in agriculture: biometrical methods for evaluating phenotypic stability in plant breeding. Cerne Outubro Dezembro, 12(4): 373388.

Kamidi R E. 2005. A parametric measure of lactation persistency in dairy cattle. Livestock Production Science., 96: 141148

Nijubi D, Rege J E O, Thorpe W, Collins L E and Nyambaka R. 1992. Genetic and environmental variations in reproductive and lactation performance of Jersey cattle in the coastal lowland sub humid tropics. Tropical Animal Health and Production, 24: 231-241.

\section{How to cite this article:}

Radhika Thakur, R.K. Gupta and Mahajan, P.K. 2019. Study on Stable Lactation of Jersey Cross Breed. Int.J.Curr.Microbiol.App.Sci. 8(03): 2052-2055. doi: https://doi.org/10.20546/ijcmas.2019.803.244 